\title{
Pengembangan Perangkat Pembelajaran Model Discovery Learning Berbasis Standar Kompetensi Kerja Nasional Indonesia (SKKNI)
}

\author{
Trisna Muliawan \\ Pendidikan Kimia, Universitas Negeri Makassar \\ Email: trisnamuliawan@gmail.com \\ Pince Salempa \\ Pendidikan Kimia, Universitas Negeri Makassar \\ Email: pince.salempa57@gmail.com \\ Sugiarti Sugiarti \\ Pendidikan Kimia, Universitas Negeri Makassar \\ Email: atisugiarti34@yahoo.co.id
}

(Diterima: 9-Januari-2021; direvisi: 10-Februari-2021; dipublikasikan: 27-Maret-2021)

\begin{abstract}
Abstrak: Penelitian ini merupakan penelitian pengembangan yang bertujuan mengembangkan perangkat pembelajaran model discovery learning berbasis SKKNI pada mata pelajaran analisis volumetri yang valid, praktis, dan efektif. Model pengembangan yang digunakan dalam penelitian ini mengacu pada model pengembangan $4 \mathrm{D}$, yang terdiri dari tahap pendefinisian (define), tahap perancangan (design), tahap pengembangan (develop), dan tahap penyebaran (disseminate). Perangkat pembelajaran yang dikembangkan adalah RPP, LKPD, Bahan Ajar Peserta Didik, dan THB. Perangkat pembelajaran volumetri model discovery learning berbasis SKKNI yang telah dikembangkan, kemudian divalidasi oleh dua orang ahli. Setelah validasi, selanjutnya dilakukan uji coba perangkat pembelajaran yang dilakukan di SMK SMAK Makassar pada kelas XI E dengan jumlah peserta didik sebanyak 35 orang. Hasil penelitian menunjukkan bahwa perangkat pembelajaran model discovery learning berbasis SKKNI yang dikembangkan setelah divalidasi berada pada kriteria sangat valid $(\mathrm{V}=3,75)$. Perangkat pembelajaran dikatakan praktis, karena pada uji kepraktisan yang berhubungan dengan: (1) keterlaksanaan perangkat pembelajaran berada pada kategori terlaksana seluruhnya $(\mathrm{M}=1,86)$ masuk dalam kategori $(1,5 \leq \mathrm{M} \leq 2,0)$, (2) guru memberikan respon yang sangat positif dengan persentase 93,49\%, dan (3) peserta didik memberikan respon yang sangat positif dengan persentase $91,93 \%$. Perangkat pembelajaran ini juga memenuhi kriteria keefektifan, yang diulas melalui hasil belajar peserta didik dengan persentase ketuntasan klasikal 94,00\%. Dengan demikian, hasil penelitian menunjukkan bahwa produk perangkat pembelajaran yang dikembangkan memenuhi kriteria valid, praktis, dan efektif.
\end{abstract}

Kata kunci: Pengembangan; Discovery Learning; SKKNI; Perangkat Pembelajaran.

Abstract: This is a development research that aims to evolve a learning instruments discovery learning model based on the SKKNI on volumetric analysis subject that are valid, practical, and effective. The development model used in this study refers to the 4D, which consists of the defining, design, development, and dissemination. The learning instruments developed are RPP, LKPD, Student Learning Materials, and THB. The SKKNI-based discovery learning model volumetric learning device that was developed was then validated by two experts. After validation, a learning device trial is then conducted at the SMK-SMAK Makassar in class XI E with a total of 35 students. The results of the study indicate that the SKKNI-based 
discovery learning model developed after being validated was very accurate $(\mathrm{V}=3.75)$. The learning device is stated to be practical because the practicality test related to: (1) the implementation of the learning device is in the fully implemented category $(M=1.86)$ included in the category $(1.5 \leq \mathrm{M} \leq 2.0)$, (2) the teacher gave a very positive response with a percentage of $93.49 \%$, and (3) the students gave a very positive response with a percentage of 91.93\%. This learning device also meets the effectiveness criteria, which are reviewed through learning outcomes with a classical percentage of completeness $94.00 \%$. Therefore, the results of the study indicate that the developed learning device products meet valid, practical, and effective criteria.

Keywords: Development; Discovery Learning; SKKNI; Learning Device.

\section{PENDAHULUAN}

Peserta didik merupakan generasi penerus yang akan menentukan masa depan bangsa, agar suatu bangsa dapat berkiprah dalam tatanan dunia baru yang cepat berubah perlu menyiapkan SDM yang berkualitas. Peningkatan kemampuan dan keterampilan bagi generasi muda calon tenaga kerja merupakan tanggung jawab dunia pendidikan. Pendidikan vokasi merupakan bagian integral yang tidak dapat dipisahkan dari proses penyiapan SDM yang berkualitas, tangguh, dan terampil. Melalui pendidikan vokasi akan diperoleh calon tenaga kerja yang berkualitas, produktif, dan mampu bersaing.

Untuk mencapai tujuan pendidikan nasional pemerintah telah menyelenggarakan perbaikan-perbaikan peningkatan mutu pendidikan pada berbagai jenis dan jenjang. Namun fakta di lapangan belum menunjukkan hasil yang memuaskan. Salah satu maslah pokok dalam pembelajaran di sekolah dewasa ini adalah masih rendahnya daya serap peserta didik. Hal ini nampak dari rerata hasil belajar peserta didik yang senantiasa masih sangat memprihatinkan. Prestasi ini tentunya merupakan hasil kondisi pembelajaran yang masih bersifat konvensional dan tidak menyentuh ranah dimensi peserta didik itu sendiri, yaitu bagaimana sebenarnya belajar itu. Dalam arti yang lebih substansial, bahwa proses pembelajaran hingga dewasa ini masih memberikan dominasi guru dan tidak memberikan akses bagi peserta didik untuk berkembang secara mandarin melalui penemuan dan proses berpikirnya.
Kurikulum yang diterapkan saat ini adalah kurikulum 2013 yang diharapkan mampu meningkatkan kemandirian peserta dalam mengelola pola pembelajaran dan penggunaan pengetahuan yang dimilikinya untuk meningkatkan daya cipta, rasa, dan karsa yang dapat diimplementasikan dalam kehidupannya. Sejalan dengan maksud tersebut, pemerintah Indonesia merevitalisasi pendidikan jalur vokasi dengan penerapan Standar Kompetensi Kerja Nasional Indonesia (SKKNI) sebagai acuan dalam pengembangan kurikulum, silabus dan modul pembelajaran (Permen Ketenagakerjaan nomor 2 pasal 15, 2016) untuk mempercepat peningkatan sumber daya manusia melalui penguasaan peserta didik tidak hanya pada aspek pengetahuan tapi juga terampil menggunakan alat-alat industri sesuai standar serta memiliki sikap kerja sesuai standar dunia kerja.

Hasil belajar adalah hasil yang dicapai seseorang karena usahanya untuk memiliki suatu kecakapan atau ilmu pengetahuan atau perubahan-perubahan yang terjadi pada tingkah laku seseorang yang dilakukannya dalam usaha untuk memiliki suatu kecakapan atau keterampilan-keterampilan tertentu dan perubahan-perubahan yang dicapai oleh individu dalam proses belajar-mengajar meliputi aspek pengetahuan, keterampilan dan sikap (Purwanto, 2001). Keberhasilan dalam proses belajar dapat mempengaruhi hasil belajar yang diperoleh peserta didik dan motivasi belajar peserta didik. Dalam kegiatan belajar, motivasi dapat dikatakan sebagai suatu keseluruhan daya penggerak 
di dalam diri peserta didik yang menimbulkan kegiatan belajar, yang menjamin kelangsungan dari kegiatan belajar dan yang memberikan arah pada kegiatan belajar sehingga tujuan yang dikehendaki oleh subjek belajar itu dapat tercapai (Sardiman, 2010).

$$
\text { Pembelajaran kimia memiliki }
$$

karakteristik yakni berisi konsep-konsep, rumus-rumus yang sulit dipahami dan kebanyakan materi yang bersifat abstrak. Materi inilah yang membuat peserta didik sulit memahami konsep yang mendasar dalam ilmu kimia. Kesulitan peserta didik dalam memahami materi ini terlihat dari observasi yang dilakukan oleh peneliti. Berdasarkan hasil observasi yang dilakukan secara langsung terhadap suasana pembelajaran di kelas menunjukkan: kebanyakan guru menggunakan metode ceramah dan peserta didik ditugaskan mencatat dan berdiskusi, penggunaan alat belajar juga sangat jarang digunakan dalam proses belajar, kemampuan peserta didik dalam menemukan informasi yang dibutuhkan pada proses pembelajaran khususnya pada materi kesetimbangan kimia masih kurang.

Berdasarkan hasil wawancara dengan salah satu guru Kimia di SMA Negeri 11 Makassar, hasil belajar kognitif peserta didik di kelas XI pada materi pokok kesetimbangan kimia masih belum optimal. Hal ini dapat diketahui dari persentase peserta didik yang belum bisa mencapai Kriteria Ketuntasan Minimal (KKM) sekitar $50 \%$. Adanya kesulitan tersebut menyebabkan keaktifan dan motivasi peserta didik dalam proses pembelajaran masih cenderung rendah dan berdampak pada hasil belajarnya. Peran guru dalam proses pembelajaran menuntut kemampuan guru untuk menggunakan model pembelajaran yang dapat meningkatkan hasil belajar peserta didik dan membuat peserta didik dapat berperan aktif.

Model pembelajaran inkuiri merupakan salah satu model yang dapat mendorong peserta didik untuk aktif dalam pembelajaran (Shoimin, 2016). Model pembelajaran inkuiri ini dapat dilaksanakan dengan tiga macam cara yaitu inkuiri terbimbing, inkuiri bebas dan inkuiri bebas yang dimodifikasi. Pada model inkuiri terbimbing, semua perencanaan proses pembelajaran dibuat oleh guru dan peserta didik dapat merumuskan masalah namun harus kembali dibimbing oleh guru agar sesuai dengan tujuan yang akan dicapai. Petunjuk mengenai cara penyusunan dan mencatat data semuanya dibuat oleh guru. (Rusman, 2016). Melalui model pembelajaran inkuiri terbimbing, peserta didik dapat melatih kemampuan kognitif, afektif, dan psikomotorik (Amri, 2013).

Pembelajaran kimia memiliki tiga aspek, yaitu makroskopis, mikroskopis dan simbolik. Ketiga aspek tersebut saling berhubungan dan harus dikuasai oleh peserta didik agar didapatkan pembelajaran yang menyeluruh (Nurhayati, 2014). Kesetimbangan Kimia merupakan aspek mikroskopis yang mengandung konsepkonsep bersifat abstrak. Kesulitan peserta didik dalam memahami materi ini terlihat dari ketidaktuntasan hasil belajar peserta didik ketika melakukan ulangan. Salah satu kemungkinan dari kekurangan ini adalah peserta didik yang mengalami kesulitan dalam memahami konsep mikroskopis dapat menimbulkan pemahaman yang salah. Apabila kesalahan ini berlangsung secara konsisten akan menimbulkan terjadinya salah konsep atau miskonsepsi. Oleh karena itu, guru dituntut untuk menggunakan media pembelajaran yang tepat untuk memudahkan peserta didik memahami konsep. Konsep yang bersifat abstrak inilah yang perlu divisualisaikan dengan menggunakan media video animasi.

Media animasi merupakan suatu tampilan yang menggabungkan antara media teks, grafik, dan suara dalam suatu aktivitas penggerakan sehingga akan membuat proses pembelajaran menjadi lebih menarik serta akan sangat bermanfaat dalam proses pembelajaran (Suryanta, dkk, 2014). Media video animasi dua dimensi (2D) ini dapat membuat materi kesetimbangan kimia yang bersifat abstrak menjadi tampak nyata, 
sehingga peserta didik dapat meningkatkan motivasi dan hasil belajarnya. Selain itu, media video animasi berupa kartun ini dapat membuat peserta didik tertarik untuk memahami pembelajaran kimia.

Berdasarkan penelitian (Sukiyasa \& Sukoco, 2013), bahwa hasil belajar dan motivasi belajar peserta didik yang menggunakan media animasi lebih tinggi dibandingkan yang menggunakan media power point. Penelitian yang dilakukan (Wardoyo, 2015) bahwa media video animasi sangat layak untuk digunakan, tes hasil belajar berada pada kategori tinggi dan minat belajar peserta didik meningkat. Selain itu terdapat penelitian (Subhan, dkk, 2018), bahwa ada pengaruh positif media animasi dalam model pembelajaran inkuiri terbimbing terhadap keterampilan berpikir kritis dan aktivitas belajar peserta didik pada materi kesetimbangan kimia.

Hasil observasi analisis kebutuhan peserta didik yang dilakukan di SMA Negeri 11 Makassar diperoleh data bahwa 97\% peserta didik tertarik mempelajari kimia dengan menggunakan media video aniasi. Berdasarkan uraian tersebut, maka dilakukan penelitian dengan judul "Pengembangan Media Pembelajaran berbasis Video Animasi dengan Model Pembelajaran Inkuiri Terbimbing untuk Meningkatkan Motivasi dan Hasil Belajar Peserta Didik (Materi Pokok Kesetimbangan Kimia)".

\section{METODE}

Penelitian ini merupakan penelitian pengembangan (Research and Development/ $R \& D) \quad$ yang bertujuan untuk mengembangkan media pembelajaran berbasis video animasi dengan model pembelajaran inkuiri terbimbing untuk meningkatkan motivasi dan hasil belajar peserta didik yang dikembangkan dengan menggunakan model pengembangan 4-D (Define, Design, Develop, Disseminate) oleh Thiagarajan (1974). Penelitian ini dilaksanakan di kelas XI MIA SMA Negeri 11 Makassar semester ganjil tahun pelajaran 2019/2020 pada tanggal 11 November 2019 - 06 Februari 2020. Subjek penelitian ini dibedakan menjadi dua bagian. Bagian pertama subjek uji coba desain produk atau uji ahli, yang terdiri dari ahli media dan ahli materi. Bagian kedua merupakan subjek uji coba produk atau uji lapangan.

Subjek pengujian desain produk atau uji ahli dilakukan oleh 2 orang yakni 1 orang sebagai ahli materi dan 1 orang sebagai ahli media. Subjek uji coba produk atau uji lapangan dilakukan dengan mengujikan media pembelajaran dikelas MA dan kelas TMA. Adapun subjek uji coba ini terdiri dari 33 orang peserta didik di kelas XI MIA 4 sebagai kelas MA dan 32 orang peserta didik kelas XI MIA 6 sebagai kelas TMA serta 2 orang guru kimia kelas XI SMA Negeri 11 Makassar. Pengembangan media video animasi yang dikembangan dalam penelitian ini merujuk pada tiga syarat kualitas, yakni valid, praktis dan efektif. Instrumen penelitian yang digunakan untuk memperoleh kevalidan adalah lembar validasi ahli media dan ahli materi. Hasil penilaian dari ahli atau validator dikatakan valid apabila penilaian oleh para ahli berada pada kategori "Sangat Valid".

Instrumen penelitian yang digunakan untuk memperoleh kepraktisan adalah lembar keterlaksanaan perangkat, angket respon peserta didik dan angket respon guru. Berdasarkan hasil pengamatan oleh observer bahwa keterlaksanaan perangkat dengan menggunakan media video animasi dikatakan baik apabila penilaian oleh observer berada pada kategori "Sangat Baik". Respon peserta didik dan guru terhadap media video animasi dikatakan baik digunakan apabila penilaian berada pada kategori "Sangat Tinggi" sehingga media video animasi dikatakan praktis untuk digunakan. Instrumen penelitian yang digunakan untuk memperoleh keefektifan media video animasi adalah lembar observasi motivasi peserta didik dan tes hasil belajar.

Berdasarkan hasil penilaian motivasi belajar dikatakan efektif apabila berada pada kategori "Sangat Tinggi". Hasil penilaian tes hasil belajar dikatakan efektif jika penilaian berada pada kategori "Sangat Tinggi" 
dibandingkan kelas yang tidak menggunakan media animasi.

\section{HASIL DAN PEMBAHASAN}

\section{Proses Pengembangan Media Pembelajaran Berbasis Video Animasi}

Media Pembelajaran berbasis video animasi pada materi kesetimbangan kimia kelas XI SMA dikembangkan dengan menggunakan model 4-D oleh Thiagrajan,dkk. Model pengembangan terdiri dari empat tahap, yang pertama tahap pendefinisian (define), dalam tahap ini dilakukan dengan tujuan untuk memenuhi kebutuhan pengembangan atau analisis kebutuhan. Hasil pendefinisian yang dilakukan pada tahap ini mencakup beberapa langkah yaitu analisis awal-akhir, analisis peserta didik, analisis konsep, analisis tugas dan perumusan tujuan pembelajaran. Berdasarkan analisis yang telah dilakukan dapat disimpulkan bahwa perlu adanya pengembangan media pembelajaran berbasis video animasi agar dapat meningkatkan motivasi peserta didik dalam mempelajari materi kesetimbangan kimia dan dengan menggunakan model pembelajaran inkuiri terbimbing peserta didik dapat aktif dalam proses pembelajaran dan peserta didik dapat menemukan konsep kimia secara mandiri sehingga hasil belajar peserta didik dapat meningkat.

Selanjutnya yang kedua tahap perencanaan (design) yaitu untuk menyiapkan rancangan awal media video animasi. Tahap perancangan ini terdiri dari 4 langkah, yaitu: (1) penyusunan tes, tes ini merupakan instrumen untuk mengukur ketuntasan indikator. Tes yang disusun merupakan tes yang berbentuk uraian dengan jumlah butir soal adalah 5 butir. (2) pemilihan media, pada tahap ini peneliti memilih media pembelajaran berbasis video animasi yang bertujuan untuk memudahkan peserta didik dalam proses pembelajaran, menarik minat peserta didik sehingga hasil belajar dan motivasi peserta didik dapat meningkat. (3) pemilihan format, pada tahap pembuatan media video animasi dengan pemilihan teks, gambar, serta bingkai video kemudian disusun sesuai dengan urutan materi yang diajarkan. Penyusunan ini dilakukan pada aplikasi powtoon, video scribe, aurora $3 D$ animation dan wondershare filmora. (4) desain awal media pembelajaran, peneliti melakukan desain awal media video animasi dengan tahapan sebagai berikut: pembuatan storyboard, penataan materi dalam media meliputi tata letak (layout) yang digunakan, pembuatan karakter tokoh animasi dan penyusunan isi materi yang mengacu pada model kontekstual dan divisualisasikan dengan penggunaan video animasi.

\section{Data Hasil Pengembangan Produk}

Hasil validasi terhadap pengembangan media video animasi dinilai oleh para ahli. Para ahli ini terdiri dari ahli media dan ahli materi. Validasi media pembelajaran berbasis video animasi oleh ahli materi dapat dilihat pada Tabel 1 .

Tabel 1. Data Hasil Validasi Oleh Ahli Materi

\begin{tabular}{llc}
\hline Aspek Yang Dinilai & \multicolumn{1}{c}{ Indikator Penilaian } & Skor \\
\hline Kelayakan Isi dan & $\begin{array}{l}\text { Kesesuaian media pembelajaran dengan } \\
\text { Penyajian }\end{array}$ & 4 \\
& $\begin{array}{l}\text { Kesesuaian materi pada media pembelajaran } \\
\text { dengan tingkat kebutuhan peserta didik }\end{array}$ & 3 \\
& Keutuhan materi dari awal hingga akhir & 4 \\
& Kesesuaian animasi media dengan materi ajar & 3 \\
& Kesesuaian soal latihan dengan materi \\
& $\begin{array}{l}\text { Penyajian materi dalam media pembelajaran } \\
\text { tampil menarik } \\
\text { Penyajian bahan kajian/topik pembahasan dapat }\end{array}$ & 3 \\
&
\end{tabular}




\begin{tabular}{lc}
\hline & \\
& memberi motivasi belajar pada peserta didik \\
Membuat peserta didik berpartisipasi aktif dalm & 3 \\
pembelajaran & \\
Kesesuaian penggunaan bahasa & 4 \\
Kemudahan pemahaman materi oleh peserta didik & 3 \\
Kemudahan memahami animasi pada media & 4 \\
Ketepatan penggunaan istilah dan simbol & 4 \\
\hline Rata-rata Skor Keseluruhan & 3,5 \\
\hline Kategori Pilihan & Sangat Valid \\
\hline
\end{tabular}

Hasil media video animasi pada materi kesetimbangan kimia oleh ahli materi menunjukkan untuk aspek kelayakan isi dan penyajian diperoleh rerata skor 3,25 dan untuk aspek kebahasaan diperoleh rerata skor 3,75. Adapun Secara keseluruhan penilaian ahli materi mencakup seluruh aspek memperoleh rerata skor 3,5, sehingga apabila dikonversikan berdasarkan tabel kriteria kevalidan media menurut Arikunto (2010), maka rerata skor tersebut termasuk pada valid. Selanjutnya validasi media pembelajaran berbasis video animasi oleh ahli media dapat dilihat pada Tabel 2.

Tabel 2. Data Hasil Validasi Oleh Ahli Media

\begin{tabular}{|c|c|c|}
\hline Aspek Yang Dinilai & Indikator & Skor \\
\hline \multirow{3}{*}{ Kualitas Produk } & Meningkatkan ketertarikan peserta didik & 4 \\
\hline & Keaslian media pembelajaran ini baik & 3 \\
\hline & Produk tidak membosankan & 4 \\
\hline \multirow[b]{2}{*}{ Efisiensi } & Video animasi ini mudah dipahami & 3 \\
\hline & $\begin{array}{l}\text { Video ini mudah digunakan dalam } \\
\text { pengoperasiannya }\end{array}$ & 4 \\
\hline \multirow{6}{*}{ Tampilan Media } & Menampilkan video yang menarik & 4 \\
\hline & Penggunaan teks yang mudah dibaca & 3 \\
\hline & $\begin{array}{l}\text { Pemilihan gambar, audio dan animasi yang } \\
\text { tepat dan menarik }\end{array}$ & 3 \\
\hline & Pemilihan komposisi warna yang tepat & 4 \\
\hline & $\begin{array}{l}\text { Kesesuaian tata letak komponen-komponen } \\
\text { dalam media }\end{array}$ & 3 \\
\hline & $\begin{array}{l}\text { Keseluruhan program tersaji secara } \\
\text { sistematis dan padat }\end{array}$ & 3 \\
\hline \multicolumn{2}{|c|}{ Rata-rata Skor Keseluruhan } & 3,49 \\
\hline \multicolumn{2}{|r|}{ Kategori Pilihan } & Sangat Valid \\
\hline
\end{tabular}

Hasil penilaian media video animasi pada materi kesetimbangan kimia oleh ahli media menunjukan untuk aspek kualitas produk diperoleh rerata skor 3,67, aspek efisiensi diperoleh rerata skor 3,5 dan untuk aspek tampilan media diperoleh rerata skor 3,3. Adapun secara keseluruhan penilaian ahli media yang mencakup seluruh aspek memperoleh rerata skor 3,49 , sehingga apabila dikategorikan, maka rerata skor tersebut termasuk pada kategori Sangat Valid. Selanjutnya berdasarkan penilaian kedua pakar validasi konstruk yang diperoleh dari hasil validasi Gregory sebesar 1,00, sehingga apabila dikonversikan berdasarkan tabel kriteria kevalidan media menurut Arikunto (2010), maka rerata skor tersebut termasuk pada kategori Sangat tinggi. Hal ini berarti kevalidan media termasuk pada kategori sangat tinggi (sangat 
valid). Untuk melihat kepraktisan media video animasi yang dikembangkan dibutuhkan data dari lembar observasi keterlaksanaan perangkat, hasil angket respon peserta didik dan guru. Uji keterlaksaan perangkat dilakukan oleh observer untuk mengetahui sejauh mana pembelajaran dapat terlaksana dengan menggunakan media pembelajaran berbasis video animasi. Hasil observasi keterlaksanaan media video animasi yang dikembangkan dapat dilihat pada Tabel 3.

Tabel 3. Rekapitulasi Hasil Observasi Keterlaksanaan Perangkat

\begin{tabular}{clcc}
\hline No & \multicolumn{1}{c}{ Aspek } & Rata-rata Persentase (\%) & Kategori \\
\hline 1 & Tahap Pendahuluan & 93,4 & Sangat Baik \\
\hline 2 & Fase Orientasi & 100 & Sangat Baik \\
3 & Fase Merumuskan Masalah & 100 & Sangat Baik \\
4 & Fase Merumuskan Hipotesis & 100 & Sangat Baik \\
5 & Fase Mengumpulkan Data & 100 & Sangat Baik \\
6 & Fase Menguji Hipotesis & 100 & Sangat Baik \\
7 & Fase Merumuskan Kesimpulan & 100 & Sangat Baik \\
8 & Tahap Penutup & 93,4 & Sangat Baik \\
\hline & Rata-rata Total & 98,35 & Sangat Baik \\
\hline
\end{tabular}

Hasil observasi secara keseluruhan terhadap keterlaksanaan pembelajaran menggunakan media video animasi diperoleh rata-rata persentase yakni 98,35\% yang termasuk dalam kategori sangat tinggi. Hasil penilaian observer menunjukkan bahwa media video animasi yang dikembangkan praktis untuk digunakan. Penilaian selanjutnya, yaitu penilaian dari peserta didik terhadap media video animasi yang digunakan pada akhir pertemuan. Hasil respon peserta didik dapat dilihat pada Tabel 4.

Tabel 4. Rekapitulasi Hasil Angket Respon Peserta Didik terhadap Media

\begin{tabular}{|c|c|c|c|c|c|}
\hline No & Aspek Penilaian & $\begin{array}{c}\text { Jumlah } \\
\text { Nilai }\end{array}$ & $\begin{array}{c}\text { Rata-rata } \\
\text { Nilai }\end{array}$ & $\begin{array}{c}\text { Persentase } \\
(\%)\end{array}$ & Kategori \\
\hline 1 & Manfaat Media & 456 & 3,455 & 86 & $\begin{array}{l}\text { Sangat } \\
\text { Tinggi }\end{array}$ \\
\hline 2 & Desain Media & 446 & 3,379 & 84 & Tinggi \\
\hline 3 & Navigasi/Pengoperasian Media & 461 & 3,492 & 87 & $\begin{array}{l}\text { Sangat } \\
\text { Tinggi }\end{array}$ \\
\hline 4 & $\begin{array}{l}\text { Kesesuaian Tujuan } \\
\text { Pembelajaran }\end{array}$ & 120 & 3,636 & 90 & $\begin{array}{l}\text { Sangat } \\
\text { Tinggi }\end{array}$ \\
\hline 5 & Kualitas Materi & 355 & 3,586 & 89 & $\begin{array}{l}\text { Sangat } \\
\text { Tinggi }\end{array}$ \\
\hline 6 & Penyajian Self Evaluation & 116 & 3,516 & 87 & $\begin{array}{l}\text { Sangat } \\
\text { Tinggi }\end{array}$ \\
\hline & Total & 1954 & 3,510 & 87 & \\
\hline
\end{tabular}

Kategori Keseluruhan Penilaian Media

Sangat Tinggi

Hasil respon terhadap media pembelajaran berbasis video animasi oleh peserta didik untuk keseluruhan aspek diperoleh persentase sebesar $87 \%$. Berdasarkan tabel kriteria tingkat respon peserta didik menurut Supardi (2015), maka 
persentase tersebut termasuk pada kategori sangat tinggi. Penilaian selanjutnya yaitu penilaian dari guru terhadap media video animasi yang dikembangkan. Hasil respon guru terhadap media yang dikembangkan dapat dilihat pada Tabel 5 .

Tabel 5. Rekapitulasi Hasil Penilaian Guru terhadap Media untuk Setiap Aspek

\begin{tabular}{|c|c|c|c|c|c|c|c|}
\hline \multirow{2}{*}{ No } & \multirow{2}{*}{ Aspek Penilaian } & \multicolumn{3}{|c|}{ Guru 1} & \multicolumn{3}{|c|}{ Guru 2} \\
\hline & & $\bar{X}$ & $\%$ & Kategori & $\bar{X}$ & $\%$ & Kategori \\
\hline 1 & $\begin{array}{l}\text { Kesesuaian Tujuan } \\
\text { Pembelajaran }\end{array}$ & 4 & 100 & $\begin{array}{l}\text { Sangat } \\
\text { Tinggi }\end{array}$ & 4 & 100 & $\begin{array}{l}\text { Sangat } \\
\text { Tinggi }\end{array}$ \\
\hline 2 & Kualitas Materi & 4 & 100 & $\begin{array}{l}\text { Sangat } \\
\text { Tinggi }\end{array}$ & 3,4 & 85 & $\begin{array}{l}\text { Sangat } \\
\text { Tinggi }\end{array}$ \\
\hline 3 & Penyajian konten materi & 3,5 & 87,5 & $\begin{array}{l}\text { Sangat } \\
\text { Tinggi }\end{array}$ & 4 & 100 & $\begin{array}{l}\text { Sangat } \\
\text { Tinggi }\end{array}$ \\
\hline 4 & Penyajian Self Evaluation & 4 & 100 & $\begin{array}{l}\text { Sangat } \\
\text { Tinggi }\end{array}$ & 4 & 100 & $\begin{array}{l}\text { Sangat } \\
\text { Tinggi }\end{array}$ \\
\hline 5 & Manfaat Media & 4 & 100 & $\begin{array}{l}\text { Sangat } \\
\text { Tinggi }\end{array}$ & 3,5 & 87,5 & $\begin{array}{l}\text { Sangat } \\
\text { Tinggi }\end{array}$ \\
\hline 6 & Desain Media & 4 & 100 & $\begin{array}{l}\text { Sangat } \\
\text { Tinggi }\end{array}$ & 3,3 & 82,5 & $\begin{array}{l}\text { Sangat } \\
\text { Tinggi }\end{array}$ \\
\hline 7 & $\begin{array}{l}\text { Navigasi / Pengoperasian } \\
\text { media }\end{array}$ & 4 & 100 & $\begin{array}{l}\text { Sangat } \\
\text { Tinggi }\end{array}$ & 4 & 100 & $\begin{array}{l}\text { Sangat } \\
\text { Tinggi }\end{array}$ \\
\hline & Jumlah & 3,9 & $97,5 \%$ & $\begin{array}{l}\text { Sangat } \\
\text { Tinggi }\end{array}$ & 3,7 & 92,5 & $\begin{array}{l}\text { Sangat } \\
\text { Tinggi }\end{array}$ \\
\hline
\end{tabular}

Hasil secara keseluruhan penilaian guru 1 terhadap media pembelajaran berbasis video animasi diperoleh persentase rata-rata respon yakni sebesar $97,5 \%$, yang jika dikonversikan berdasarkan tabel kriteria respon guru menurut Supardi (2015), maka termasuk dalam kategori sangat tinggi. Sementara untuk Guru 2 diperoleh presentase rata-rata respon sebesar $92,5 \%$, yang jika dikonversikan juga berdasarkan tabel kriteria respon guru menurut Supardi (2015), maka termasuk dalam kategori sangat tinggi. Berdasarkan hasil respon guru terhadap media pembelajaran berbasis video animasi yang dikembangkan praktis untuk digunakan dalam pembelajaran. Hasil penelitian ini sesuai dengan teori yang dijelaskan Sadiman (2008) media animasi dapat menarik perhatian pelajar karena adanya rangsangan untuk berpikir sehingga membuat pelajaran lebih berkesan.

Keefektifan media video animasi yang dikembangkan dapat dilihat dari data motivasi belajar peserta didik, hasil belajar peserta didik dan membandingkan dua kelas terhadap hasil belajar. Motivasi belajar peserta didik kelas MA dan TMA dapat dilihat pada Tabel 6 .

Tabel 6. Hasil Analisis Motivasi Belajar Kelas MA dan TMA

\begin{tabular}{clcc}
\hline \multirow{2}{*}{ No } & \multicolumn{1}{c}{ Indikator } & \multicolumn{2}{c}{ Kelas } \\
\cline { 3 - 4 } & & Kelas MA & $\begin{array}{c}\text { Kelas } \\
\text { TMA }\end{array}$ \\
\hline 1 & Semangat dan tekun mengerjakan tugas & 82,07 & 82,55 \\
2 & $\begin{array}{l}\text { Ulet menghadapi kesulitan/tidak mudah putus asa } \\
\text { guna mencapai suatu tujuan }\end{array}$ & 83,08 & 84,11 \\
3 & $\begin{array}{l}\text { Memperhatikan guru saat menjelaskan materi } \\
\text { pelajaran }\end{array}$ & 80,11 & 84,57 \\
4 & Senang bekerja/mengerjakan tugas atas kemauan & 86,74 & 89,84
\end{tabular}


sendiri

5 Termotivasi oleh situasi dan lingkungan belajar

$90,15 \quad 80,08$

$6 \quad$ Senang memecahkan masalah soal-soal

$86,36 \quad 81,64$

7

Semangat berkompetisi dalam menyampaikan dan

mempertahankan pendapatnya

$82,77 \quad 83,40$

Rata-rata

81,33

71,41

Hasil rerata motivasi belajar peserta didik kelas MA lebih tinggi dibandingkan dengan kelas TMA. Hal ini menunjukkan bahwa media pembelajaran berbasis video animasi dapat meningkatkan motivasi belajar peserta didik. Hasil penelitian ini sesuai dengan teori dari Rusman et al
(2012), salah satu fungsi media pembelajaran yaitu dapat membangkitkan perhatian dan motivasi peserta didik serta dapat meningatkan hasil belajar peserta didik.Tes hasil belajar peserta didik untuk kelas MA dan kelas TMA dapat dilihat pada Tabel 7.

Tabel 7. Analisis Deskriptif Hasil Belajar Kelas MA dan TMA

\begin{tabular}{lcc}
\hline \multirow{2}{*}{\multicolumn{1}{c}{ Variabel }} & \multicolumn{2}{c}{ Nilai Deskriptif } \\
\cline { 2 - 3 } & Kelas MA & Kelas TMA \\
\hline Subjek Penelitian & 33 & 32 \\
Nilai Ideal & 100 & 100 \\
Nilai KKM & 75 & 75 \\
Skor Maksimum & 100 & 92,5 \\
Skor Minimum & 50 & 35 \\
Jumlah Peserta Didik yang Tuntas & 28 & 24 \\
Jumlah Peserta Didik yang Tidak Tuntas & 5 & 8 \\
\hline Presentase Ketuntasan Kelas & $84,8 \%$ & $75 \%$ \\
\hline
\end{tabular}

Berdasarkan data tes hasil belajar diperoleh peserta didik kelas MA yang tuntas lebih banyak dibandingkan kelas TMA dan presentase ketuntasan kelas pada kelas MA lebih tinggi dari kelas TMA yang dapat disimpulkan bahwa media video animasi efektif untuk digunakan dalam proses pembelajaran. Untuk melihat keefektifan media animasi terhadap hasil belajar dilakukan dengan uji statistik deskriptif. Untuk melihat apakah perbedaannya terjadi secara signifikan atau tidak, maka dilakukan uji hipotesis menggunakan uji-t (Independent t-test) apabila memenuhi uji prasayarat yakni normalitas dan homogenitas. Uji normalitas pada data hasil belajar kedua kelas dengan uji Kolmogorov-Smirnof dan Shapiro-Wilk pada aplikasi SPSS 24 for Windows dengan batas kritis $\alpha=0,05$. Adapun hasil uji normalitas ditunjukkan pada Tabel 8.

Tabel 8. Hasil Uji Normalitas Hasil Belajar Kelas MA dan Kelas TMA

\begin{tabular}{ccccccc}
\hline \multirow{2}{*}{ No } & \multirow{2}{*}{ Kelas } & \multicolumn{2}{c}{ Kolmogorov-Smirnov } & \multicolumn{2}{c}{ Shapiro-Wilk } & \multirow{2}{*}{ Keterangan } \\
\cline { 3 - 6 } & & Df & Sig. & df & Sig. & \\
\hline 1 & Kelas MA & 33 & .001 & 33 & .017 & Tidak Normal \\
2 & Kelas TMA & 32 & .000 & 32 & .000 & Tidak Normal \\
\hline
\end{tabular}

Hasil menunjukkan Nilai $<\alpha 0,05$ yang berarti data tidak Signifikansi (p Value) kedua uji di atas berdistribusi normal. Sementara Uji 
prasyarat kedua adalah uji homogenitas. Untuk uji homogenitas dilakukan dengan uji homogenitas Levene's test pada aplikasi SPSS 24 for Windows dengan hasil yang ditunjukkan pada Tabel 9.

Tabel 9. Hasil Uji Homogenitas Hasil Belajar Kelas MA dan Kelas TMA

\begin{tabular}{ccccc}
\hline No & Kelas & Levene Statistic & Signifikansi & Keterangan \\
\hline 1 & Kelas MA & 3.696 & 0,059 & Homogen \\
2 & Kelas TMA & & & \\
\hline
\end{tabular}

Pada tabel uji homogenitas menggunakan metode Levene's test. Hasil menunjukkan nilai Sig ( $p$ value) $0,059>\alpha$ 0,05 yang berarti varians kedua kelompok homogen. Dari hasil kedua uji prasyarat ditemukan bahwa data kedua kelompok tidak berdistribusi normal namun tetap homogen, maka uji hipotesis tidak dapat dilanjutkan menggunakan uji Independent sample t-test namun menggunakan uji statistic non-parametrik Mann-Whitney $U$ Test untuk melihat perbedaan kedua kelompok. Hasil uji Mann-Whitney U Test ditunjukkan pada Tabel 10.

Tabel 10. Hasil Uji Mann-Whitney U Test pada Kelas MA dan Kelas TMA

\begin{tabular}{ccccccc}
\hline No & Kelas & N & $\begin{array}{c}\text { Mean } \\
\text { Rank }\end{array}$ & $\begin{array}{c}\text { Nilai Mann- } \\
\text { Whitney U }\end{array}$ & Nilai Z & Signifikansi \\
\hline 1 & Kelas MA & 33 & 38,16 & 331,000 & $-2,459$ & 0,014 \\
2 & Kelas TMA & 32 & 26,84 & & \\
\hline
\end{tabular}

Hasil menunjukkan nilai signifikansi ( $p$ value) terlihat $0,014<\alpha 0,05$ yang berarti terdapat perbedaan bermakna antara dua kelompok sehingga dapat disimpulkan bahwa media video animasi efektif untuk digunakan. Hasil penelitian ini sesuai dengan teori dari Sadiman (2008) media animasi dapat menarik perhatian pelajar karena adanya rangsangan untuk berpikir sehingga membuat pelajaran lebih berkesan. Menurut penelitian yang dilakukan (Wardoyo, 2015) bahwa media video animasi sangat layak untuk digunakan, tes hasil belajar berada pada kategori tinggi dan minat belajar peserta didik meningkat. Selain itu, menurut Sukiyasa dan Sukoco (2013) dalam penelitiannya menjelaskan bahwa hasil belajar dan motivasi belajar peserta didik yang menggunakan media animasi lebih tinggi dibandingkan yang menggunakan media power point.

\section{SIMPULAN DAN SARAN}

Berdasarkan hasil penelitian, maka kesimpulan dari penelitian ini adalah media pembelajaran berbasis video animasi dengan model pembelajaran inkuiri terbimbing pada materi kesetimbangan kimia dikembangkan dengan menggunakan model pengembangan 4D oleh Thiagrajan 4 tahap, yaitu pendefenisian (define), perancangan (design), pengembangan (develop), dan tahap penyebaran (dessiminate) diperoleh media pembelajaran berbasis video animasi yang valid, praktis, dan efektif.

Berdasarkan hasil validasi oleh ahli media dan ahli materi pada media video animasi dikategorikan "Sangat Valid", berdasarkan hasil pengamatan oleh observer bahwa keterlaksanaan perangkat dengan menggunakan media video animasi berada pada kategori "Sangat Baik". Respon guru dan peserta didik berada pada kategori "Sangat Tinggi" dan berdasarkan motivasi belajar dan tes hasil belajar, pembelajaran yang menggunakan media video animasi berada pada kategori "Sangat Tinggi" dibandingkan pembelajaran yang tidak menggunakan media video animasi. Berdasarkan hasil penelitian, 
maka dikemukakan saran-saran sebagai berikut: Bagi guru disarankan untuk menggunakan media pembelajaran berbasis video animasi ini sebagai media pembelajaran yang digunakan dalam materi kesetimbangan kimia pada model pembelajaran inkuiri terbimbing. Bagi peneliti selanjutnya yang ingin melakukan penelitian yang serupa hendaknya melakukan penelitian dan pengkajian untuk menerapkan media video animasi pada model pembelajaran yang lain atau materi pokok yang lain.

\section{DAFTAR RUJUKAN}

Amri, S. (2013). Pengembangan dan model pembelajaran dalam kurikulum 2013. Jakarta: Prestasi Pustaka.

Arikunto, S. (2010). Prosedur Penelitian. Jakarta: Rineka Cipta.

Gulo, S. (2019). Tantangan Pendidikan di Era Revolusi 4.0. from KOMPASIANA.

Nurhayati, S. (2014). Pengaruh VideoAnimasi Terhadap Hasil Belajar Siswa Kelas XI SMAN 5 Pontianak pada Materi Kesetimbangan Kimia. Program Studi Pendidikan Kimia Jurusan Pendidikan Mipa Fakultas Keguruan Dan Ilmu Pendidikan Universitas Tanjungpura. Pontianak.

Purwanto, N. (2001). Prinsip-prinsip dan teknik evaluasi pengajaran. Bandung, Indonesia: Remaja Rosdakarya.

Rusman, Kurniawan, D., \& Riyana, C. (2012). Pembelajaran Berbasis Teknologi Informasi dan Komunikasi. Jakarta: Rajawali Pers.

Rusman. (2016).

Model-Model Pembelajaran Mengembangkan Profesionalisme Guru. Depok: PT Rajagrafindo Persada.

Sadiman, A. S. (2008). Media Pendidikan: Pengertian, Pengembangan, dan Pemanfaatannya. Jakarta: Rajawali Pers/PT Raja Grafindo Persada.

Sardiman, A. M. (2010). Interaksi dan motivasi belajar mengajar. Jakarta: PT Raja Grafindo.
Shoimin, A. (2016). 68 Model Pembelajaran Inovatif dalam Kurikulum 2013. Cetakan II. Yogyakarta: AR-RUZZ MEDIA.

Subhan., Salempa, P., \& Danial, M. (2018). Pengaruh Media Animasi Dalam Model Pembelajaran Inkuiri Terbimbing Terhadap Keterampilan Berpikir Kritis Dan Aktivitas Belajar Peserta Didik Pada Materi Kesetimbangan Kimia. Chemistry Education Review (CER). 1(2).

Sukiyasa, K., \& Sukoco, S. (2013). Pengaruh media animasi terhadap hasil belajar dan motivasi belajar siswa materi sistem kelistrikan otomotif. Jurnal Pendidikan Vokasi. $3(1)$.

Supardi. (2015). Penilaian Autentik Pembelajaran Afektif, Kognitif, dan Psikomotorik (Konsep dan Aplikasi). Jakarta: Rajawali Pers.

Suryanta, I M., Abadi, I. B. G. S., \& Asri, I. G. A. S. (2014). Pengaruh Model Pembelajaran Scramble Berbantuan Media Gambar Animasi Terhadap Hasil Belajar Ipa Siswa Kelas V Sd Gugus Yos Sudarso Denpasar. MIMBAR PGSD Undiksha. 2(1).

Thiagarajan, S., Semmel, D. S \& Semmel, M. I. (1974). Instructional Development for Training Teachers of Expectional Children. Minneapolis. Minnesota: Leadership Training Institute/Special Education, University of Minnesota.

Wardoyo, T. C. T. (2015). Pengembangan Media Pembelajaran Berbasis Video Animasi Pada Mata Pelajaran Meknika Teknik di SMK Negeri 1 Purworejo. Program Studi Pendidikan Teknik Sipil dan Perencanaan Fakultas Teknik Universitas Negeri Yogyakarta. Yogyakarta. 